Volume 3 No. 1, Juni 2018

P ISSN 2442-594X | E ISSN 2579-5708

http://journal.iainlangsa.ac.id/index.php/tibyan

DOI: $10.32505 /$ tibyan.v3i1.477

\title{
POTRET KARAKTERISTIK KEPEMIMPINAN PEREMPUAN \\ (Analisis Semiotika Surat Al-Naml: 23-44)
}

\author{
Portrait Of Women's Leadership Characteristics (Semiemetic Analysis \\ Surah Al-Naml: 23-44)
}

Syafieh

IAIN Zawiyah Cot Kala Langsa

syafiehyanti@gmail.com

Nurbaiti

IAIN Zawiyah Cot Kala Langsa

nurbaiti.sistalala12@gmail.com

\begin{abstract}
This article discusses about the characteristic of woman leadership which described in the Alquran. The Alquran specifically dokumenting a women who success leading her country in al-Naml. Moreover in the letter of the verse the are signs or symbols of interest that indicate the characteristic of leadership. Therefore, interest to research by using semiotic. Through a semiotic understanding, on surah An-Naml verse 23-44 not only describes the existence of woman leadership, but also describes the characteristics of Balqis in leading the country of Saba'. Some of the Balqis's characteristic leadership are democrasy, wisdom, intelligent, diplomasy and she also loves peace. This story shows that phenomeno woman leadership there was in Alquran and she has good characteristics of woman leadership.
\end{abstract}

Keywords: Woman Leadership, Queen Balqis, Semiotics

\begin{abstract}
Abstrak
Artikel ini membahas tentang karakteristik kepemimpinan perempuan yang dijelaskan dalam Alquran. Alquran secara khusus mendokumentasikan seorang wanita yang sukses memimpin negaranya di al-Naml. Terlebih lagi di surat ayat itu adalah tanda-tanda atau simbol-simbol yang menarik yang menunjukkan karakteristik kepemimpinan. Oleh karena itu, minat untuk melakukan penelitian dengan menggunakan semiotika. Melalui pemahaman semiotik, pada surah AnNaml ayat 23-44 tidak hanya menggambarkan keberadaan kepemimpinan perempuan, tetapi juga menggambarkan karakteristik Balqis dalam memimpin negara Saba '. Beberapa dari kepemimpinan karakteristik Balqis adalah demokratisasi, kebijaksanaan, cerdas, diplomasi dan dia juga mencintai perdamaian. Cerita ini menunjukkan bahwa kepemimpinan wanita fenomeno ada di Alquran dan dia memiliki karakteristik kepemimpinan wanita yang baik.
\end{abstract}

Keywords: Kepemimpinan Perempua, Ratu Balqis, Semiotika 


\section{Pendahuluan}

Kajian mengenai status perempuan dalam studi Islam sampai sekarang ini masih tetap menjadi isu yang menarik untuk dibahas. Terlebih mengenai isu kepemimpinan perempuan, memang tidak bisa dipungkiri akan terjadinya pro dan kontra apalagi dihubungkan dengan konsep kesetaraan gender. Hal ini disebabkan karena ayat Alquran dan Hadis secara tekstual lebih mengutamakan kepemimpinan laki-laki atas perempuan. Di sisi lain, banyak perempuan yang mempunyai keterampilan dalam hal kepemimpinan, serta berpengaruh besar dalam masyarakat, namun tidak diberikan peluang untuk berkiprah dalam tampuk kepemimpinan.

Realita sosial hari memperlihatkan tidak jarang seorang perempuan yang menjadi pemimpin seperti kepala daerah, gubernur bahkan presiden. Sehingga memunculkan sebuah pertanyaan apakah sosok seorang perempuan mampu dalam memimpin? Sejarah telah menjawab bahwa sosok-sosok perempuan seperti Indira Gandi, Margaret Techer, Benazir Butho yang merupakan bukti sejarah bahwa perempuan telah mengalami perubahan dan berhasil dalam memimpin. Di Aceh juga pernah dipimpin oleh empat orang ratu yang berhasil dalam mengatur kebijakan politik pemerintahan dan perlawanan terhadap belanda pada masa itu, seperti ratu Safiatuddin, Malayati dan lain sebagainya.

Alquran secara khusus menceritakan kisah Balqis dalam memimpin negeri Saba' yang super power yang diabadikan dalam surat al-Naml ayat 23 hingga 44. Ini menunjukkan bahwa pernah ada sosok perempuan yang yang mengendalikan kekuasaan yang disekelilingnya terdapat banyak tokoh laki-laki. Selain itu dalam kisah tersebut terdapat simbol-simbol yang menarik untuk diteliti lebih laanjut dengan menggunakan kajian semiotika Alquran. Oleh karena itu, tulisan ini akan mengangkat rumusan masalah sebagai berikut: 1). Bagaimana persepsi Alquran terhadap keberadaan kepemimpinan perempuan dalam surat an-Naml: 23 hingga 44? 2). Bagaimana karakteristik kepemimpinan perempuan yang ideal yang diceritakan dalam surat alNaml: 23-44 perspektif semiotika Alquran?

Jenis penelitian ini adalah library reseacrh, sumber datanya adalah Alquran serta beberapa referensi lainnya seperti kitab kisah Alquran, buku-buku, jurnal-jurnal serta penelitian-penelitian lainnya yang terkait dengan tulisan ini. Penelitian ini menggunakan semiotika yaitu dengan melihat teks Alquran dengan melihat secara heuristik dan retroaktif. Penelitian ini dilakukan dengan menemukan kata, kosa kata, kalimat dan ayat dalam kisah ratu Balqis kemudian mengamati keutuhan makna dan kandungan ayat tersebut. Data yang telah dihimpun kemudian dianalisis dengan menggunakan ilmu semiotika Alquran. Selanjutnya, memilah data dan mengklasifikasi sesuai dengan rumusan masalah penelitian tersebut.

\section{Kajian Semiotika dalam Kisah Alquran}

Kata semiotika secara bahasa berasal dari kata seme yaitu dari bahasa Yunani yang berarti tanda, ada juga yang berpendapat bahwa semiotika berasal dari kata 
semeion yaitu tanda. ${ }^{1}$ Sedangkan secara istilah semiotika adalah ilmu yang mempelajari tentang tanda-tanda atau simbol yang memiliki makna-makna tertentu. Awal munculnya istilah semiotika ketika abad ke-20 yaitu lahirnya strukturalisme yang kemudian disusul dengan semiotika. Sebenarnya pemikiran terhadap tanda sudah ada sejak zaman Yunani dan mereka juga sudah memikirkan tentang fungsi tanda. Istilah semiotika tersebut baru digunakan pada abad ke-18 kemudian baru disusul dengan memikirkan sistematika tanda pada abad ke-20. ${ }^{2}$

Istilah semiotika ini diperkenalkan oleh dua tokoh yang terkenal dalam bidangnya yang disebut juga dengan bapak semiotika modern yaitu Ferdinand de Saussure (18571913) dan Charles Sanders Peirce (1839-1914). Saussure mengembangkan semiotikanya di Perancis, sedangkan Peirce mengembangkan semiotikanya di Amerika. ${ }^{3}$ Jadi mereka tidak saling mengenal dan memiliki konsep yang berbeda dalam penerapannya, dikarenakan latar belakang kedisiplinan ilmu yang dimilikinya. Sausure adalah ahli bahasa atau linguistik, sedangkan Pierce ahli di bidang filsafat dan logika. Setelah Saussure, dikembangkan oleh muridnya yaitu Roland Barthes.

Konsep semiotika yang diperkenalkan oleh Ferdinand De Saussure melalui dikotomi sistem tanda: signified (penanda) dan signifier (petanda) atau signifie dan significant. Penanda adalah aspek material dari bahasa yaitu apa yang dikatakan atau yang didengarkan atau apa yang ditulis atau apa yang dibaca. Petanda adalah aspek mental dari bahasa, yaitu gambaran mental, pikiran dan konsep. ${ }^{4}$

Teori Pierce telah menyempurnakan teori De Saussure, dimana objek tersebut benar-benar merepresentasikan maknanya. Misalnya seseorang dalam menyebutkan kata "sepatu" maka orang akan memikirkan sepatu yang berbeda-beda, ada sepatu boots, wedges, heels, pantofel dan lain sebagainya. Oleh karena itu, Pierce membuat komunikasi lebih mudah supaya tidak akan terjadi kesalahpahaman dalam mengartikan suatu objek.

Menurut Pierce dalam memahami semiotika terdapat tiga elemen dasar utama yaitu sign, object dan interpretant. Tanda (sign) adalah sesuatu yang berbentuk fisik yang dapat ditangkap oleh panca indera manusia dan merupakan sesuatu yang merujuk (merepresentasikan) hal lain di luar tanda itu sendiri. Sedangkan acuan tanda ini disebut dengan object. Object atau acuan tanda adalah konteks sosial yang menjadi referensi dari tanda atau sesuatu yang dirujuk tanda. Interpretant atau pengguna adalah konsep pemikiran dari orang yang menggunakan tanda dan menurunkannya ke suatu makna tertentu atau makna yang ada dalam benak seseorang tentang objek yang dirujuk oleh sebuah tanda.

9.

${ }^{1}$ Imron, Semiotika Alquran: Metode dan Aplikasi terhadap Kisah Yusuf(Teras: Jakarta, 2011), h.

${ }^{2}$ Khusnul Khatimah, Semiotika: Sebuah Pendekatan dalam Studi Agama (Komunika: Jurnal Dakwah dan Komunikasi, Vol. 2 No. 2, 2008), h. 24.

${ }^{3}$ Imron, Semiotika Alquran, h. 13.

${ }^{4}$ Imron, Semiotika Alquran, h.14. 
Roland Barthes mengembangkan semiotika Saussure yang lebih menekankan interaksi antara teks dengan pengalaman personal dan kultural pengunanya, interaksi antara konvensi dalam teks dengan konvensi yang dialami dan diharapkan oleh penggunanya, karena Saussure tidak memandang kontekstualitas atas suatu teks, artinya kalimat atau bahasa yang sama bisa saja menyampaikan makna yang berbeda dalam situasi yang berbeda pula. Gagasan Barthes ini dikenal dengan "order of signification", mencakup denotasi (makna sebenarnya sesuai dengan kamus) dan konotasi (makna ganda yang lahir dari pengalaman kultural dan personal). ${ }^{5}$ Di sinilah titik perbedaan Sausure dan Barthes meskipun Barthes tetap mempergunakan istilah signifier-signified yang diusung oleh Saussure.

Semiotika merupakan salah satu ilmu yang mengkaji tentang tanda-tanda. Dalam Alquran terdapat banyak tanda-tanda yang memiliki banyak arti dan makna. Oleh karena itu, kajian semiotika merupakan salah satu disiplin ilmu yang dapat digunakan untuk mengkaji Alquran. Oleh karena itu, semiotika Alquran dapat didefinisikan sebagai cabang ilmu dari semiotika yang mengkaji tentang tanda-tanda yang terdapat dalam Alquran, dengan menggunakan konvensi-konvensi yang terdapat dalam Alquran.

Kajian Alquran dengan pendekatan semiotika termasuk kajian filsafat kontemporer. Sebab dalam pandangan Thaba' Thaba'i, para filosof Islam pada zaman klasik juga sering menggunakan filsafat dalam memahami ayat-ayat Alquran. Filosof Islam Al-Farabi dan Ibn Sina misalnya, dalam menafsirkan Alquran selalu menggunakan filsafat dalam penafsirannya. ${ }^{6}$

Teks Alquran merupakan sekumpulan tanda yang di dalamnya terdapat hubungan dialektika antara signifiant (penanda) dan signifie (petanda). ${ }^{7}$ Penanda Alquran adalah wujud teks yang berupa bahasa Arab yang meliputi huruf, kata, kalimat, ayat, surat maupun hubungan masing-masing unsur. Kompleksitas unsur-unsur yang saling berhubungan tersebut juga termasuk tanda Alquran. Petanda Alquran adalah aspek moral atau mental atau konsep yang berada dibalik penanda Alquran. Hubungan antara penanda dan petanda Alquran ditentukan oleh konvensi yang melingkupi teks tersebut. $^{8}$

Dalam semiotika terdapat dua model pembacaan yang dilakukannya yaitu pembacaan heuristik dan pembacaan retroaktif. Pembacaan heuristik adalah pembacaan berdasarkan konvensi bahasa atau berdasarkan konvensi sistem semiotika tingkat pertama. Pembacaan retroaktif adalah pembacaan pada tingkat kedua. Pembacaan heuristik lebih kepada analisis terhadap aspek linguistik yang sangat penting untuk mencari makna pada semiotika tingkat pertama. Pada heuristik ini memaparkan yang mendetail dan terperinci penjelasan ayat dari segi bahasa, yaitu

${ }^{5}$ Rahmat Kriyantono, Teknik Praktis Riset Komunikasi (Jakarta: Kencana, 2007), h. 263.

${ }^{6}$ Syafieh, "Perkembangan Filsafat Falsafi Dalam Ranah Pemikiran Islam:, Jurnal At-Tibyan, Vol. II

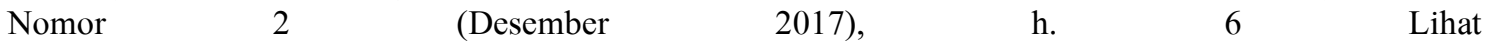
http://journal.iainlangsa.ac.id/index.php/tibyan/article/view/385diakses tanggal 15 Juni 2018

${ }^{7}$ Imron, Semiotika Alquran, h. 41.

${ }^{8}$ Imron, Semiotika Alquran, h. 42. 
melihat arti kosa kata dalam mufradat Alquran, asbabun nuzul, munasabah ayat dan lain sebagainya.

Selanjutnya pembacaan retroaktif lebih kepada makna tersirat atau makna dibalik suatu teks yang mengandung pesan-pesan filosofi yang diungkapkan dalam teks yang didapatkan dalam menghubungkan atau mengaitkan antar bagian dengam yang lainnya. Kajian semiotika menjadi bagian penting dalam proses mencari makna kisah yaitu makna dibalik kisah tersebut.

\section{Persepsi Alquran Terhadap Keberadaan Kepemimpinan Perempuan}

Alquran surat al-Naml: 23-44 telah mengabadikan kisah keberadaan kepemimpinan perempuan. Kisah kepemimpinan yang diceritakan dalam surat tersebut adalah kisah ratu Balqis yang hidup pada masa Nabi Sulaiman. Kisah Balqis dimulai ketika burung Hud-hud terbang jauh dan menemukan sebuah kerajaan besar ${ }^{9}$, sebagaimana Firman Allah dalam surat an-Naml: 23

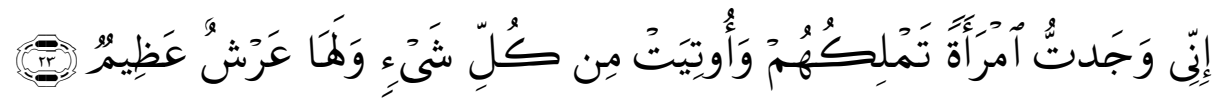

Artinya:"Sungguh kudapati ada seorang perempuan yang memerintah mereka, dan dia dianugerahi segala sesuatu serta memiliki singgsana yang besar." (Q.S. anNaml [27] : 23)

Pada awal ayat tersebut menggunakan diksi inni yang menunjukkan akan taukid (menguatkan) dan kemudian dilanjutkan dengan kata wajada. Adanya taukid dalam ayat tersebut menujukkan bahwa benar ada seorang perempuan yang memimpin negeri Saba'. Asal kata wajada adalah wajada-yajidu-wajdan. Dalam Mufradāt fî Garīb alQur'ān disebutkan kata wajada menunjukkan akan adanya penglihatan dan penyaksian dalam mendapatka sesuatu. ${ }^{10}$ Dalam ayat tersebut dapat kita pahami bahwa burung Hud-hud berhasil menemukan informasi secara langsung dan melihat dengan mata sendiri, dengan kata lain, Hud-hud benar-benar mengamati dan melihat secara langsung keberadaan dan kondisi kerajaan tersebut.

Kata imra'ah dalam ayat tersebut menunjukkan seorang perempuan dan disebutkan secara nakirah (umum), serta tidak disebutkan secara pasti dan jelas namanya dalam ayat tersebut, karena dalam ayat tersebut hanya menggunakan damir (kata ganti). Ulama tafsir sepakat bahwa yang dimaksud dengan imra'ah pada ayat tersebut adalah Balqis bin Surahail, sang ratu Saba'. ${ }^{11}$ Para mufasir berbeda pendapat tentang nama serta keturunan ayah dan ibunya. Qatadah berkata bahwa ibunya dalah jin wanita. Ibnu Juraij berkata ibunya adalah Balta'ah. Abdurrazaq berkata bahwa

\footnotetext{
${ }^{9}$ Hamid Ahmad Ath-Thahari, Kisah-Kisah dalam Alquran (Bandung: Irsyad Baitus Salam, 2012), h. 200.

${ }^{10}$ Muhammad Husain al-Așfahānī, Mufradāt fì Garīb al-Qur'ān (Beirut: Dāral-Makrifah, 502 H), h. 513.

${ }^{11}$ Ibnu Katsir, Tafsir al-Qur'an al-Az̄im (Beirut: Darul Makrifah), h. 401.
} 
wanita tersebut berasal dari kerajaan Saba' yang memiliki 312 pemimpin musyawarah, dimana setiap satu orang pemimpin memiliki anggota 10.000 orang. ${ }^{12}$

Dalam kitab tafsir al-Kasysyāf disebutkan bahwa ayahnya adalah seorang raja di negeri Yaman. ${ }^{13}$ Ayahnya mewarisi kerajaan dari ayahnya dan ia adalah anak yang ke40 dari saudaranya yaitu ia adalah anak yang terakhir. Ayahnya mempunyai kerajaan yang besar dan ia tidak mempunyai anak laki-laki seorang pun, yang hanya adalah seorang perempuan yaitu Balqis. Oleh karena itu, yang mewarisi kerajaan ayahnya adalah Balqis. Untuk data yang akurat, penulis tidak mengetahuinya secara jelas mengenai nama ayah dan ibunya karena tidak disebutkan dengan jelas dalam Alquran dan tidak ada hadis shahih yang menjelaskannya.

Frase tamlikuhum berasal dari kata malaka-yamliku-mulkan-malakah-malikah yang artinya mempunyai sesuat $u^{14}$ yang berarti juga memerintah atau berkuasa atas suatu kaum. Damir hum (kata ganti untuk mereka) merupakan bentuk jamak yang kembali kepada kaum Saba' yaitu keturunan nenek moyangnya. ${ }^{15}$ Jadi, frase tamlikuhum bermakna adalah seorang perempuan yang memerintah atau memimpin kaum Saba' yaitu ratu Balqis.

Kalimat wa ùtiyat kulli syai'in (dan dianugerahi segala sesuatu), yang terdapat kata "syai'in" merupakan isyarat tentang kekuasaan, kekayaan, peradaban kekuatan dan kemegahannya. ${ }^{16}$ Quraish Shihab mengatakan yang dimaksudkan dengan kata "syai'in" dalam ayat tersebut adalah segala sesuatu yang menjadikan suatu pemerintahan berhasil seperti tanah yang sabur, penduduk yang taat, kekuatan senjata yang tangguh, dan pemerintahan yang stabil. ${ }^{17}$ Jadi, dapat kita pahami maksud kata "syai'in" dalam ayat tersebut adalah segala sesuatu yang menunjukkan akan kemegahan dan kehebatan kerajaannya.

Frase wa lahā 'arsyun 'azim (serta memiliki singgsana yang besar) yaitu harta benda yang dibutuhkan oleh suatu kerajaan atau pemerintahan. Singgasana yang besar adalah singgasana yang tempat duduknya besar serta dihiasi emas dan bermacam mutiara dan berlian yang menunjukkan kan istana yang berkilau dan menjulang tinggi. ${ }^{18}$ Kata 'arsyun merupakan kata mufrad (tunggal), jamaknya adalah 'urusy yang berarti singgasana, tahta dan kerajaan. ${ }^{19}$. Singgasana itu sendiri mempunyai arti kursi kerajaan untuk tempat duduk raja atau tahta. Menurut Sayyed Qutub, kalimat wa lahā 'arsyun 'azim adalah singgasana yang menunjukkan kekayaan, kesejahteraan dan

${ }^{12}$ Ibnu Katsir, Tafsir al-Qur'an al-Az̄im, h. 402.

${ }^{13}$ Zamaksyari, Tafsir al-Kasyaf, (Beirut: Darul Makrifah), h. 446.

${ }^{14}$ Mahmud Yunus, Kamus Arab-Indonesia (Jakarta: Hidakarya Agung, 1989), h. 56.

${ }^{15}$ Ibnu Katsir, Tafsir al-Qur'an al-'Azīim, h. 403.

${ }^{16}$ Sayyed Qutubi, Fi Dilal al-Qur'an, Terj.M. Misbah \& Aunur Rafiq Shalih Tamhid (Jakarta: Rabbani Pres, 2009), h. 450.

${ }^{17}$ Quraish Shihab, Tafsir Al-Misbah: Pesan, Kesan dan Keserasian Alquran (Jakarta: Lentera Hati, 2002), h. 211.

${ }^{18} \mathrm{Ibnu}$ Katsir, Tafsir al-Qur'an al-'Azìm, h. 405.

${ }^{19}$ Mahmud Yunus, Kamus Arab-Indonesia, h. 18. 
kemajuan indutri. ${ }^{20}$ Berdasarkan penjelasan tersebut maksud kalimat 'arsyun 'ażim menunjukan akan kehebatan dan kemegahan kerajaan tersebut.

Hal ini menunjukkan bahwa Alquran telah menggambarkan sosok pemimpin perempuan yang berhasil membawa rakyatnya sejahtera dan kehidupan makmur yang memiliki kerajaan yang besar. Ini mengisyarakatkan dan mendokumentasikan bahwa pernah ada sosok pemimpin perempuan yang eksis dalam wilayah publik yang mempunyai kemandirian politik serta karakteristik kepemimpinan dalam mengayomi rakyatnya seperti yang akan dibahas dalam pembahasan selanjutnya.

\section{Karakteristik Kepemimpinan Perempuan yang Ideal dalam Surat al-Naml: 23-44}

Berikut adalah karakteristik kepemimpinan Balqis dalam memimpin kerajaan Saba' yang digambarkan dalam Alquran.

\section{Pemimpin yang Bijaksana dan Demokrasi}

Setelah Hud-hud memaparkan dan memberitahukan tentang kerajaan Saba' kepada Sulaiman. Sulaiman tidak langsung mempercayai apa yang telah disampaikan oleh Hud-hud. Beliau ingin menguji kebenaran berita yang disampaikannya dengan cara mengirimkan surat kepada Balqis dan memerintahkan kepada Hud-hud untuk mengantarkan surat tersebut. Ketika Balqis menerima surat tersebut, ia tidak langsung memutuskan keputusan dengan sendirinya, akan tetapi ia mengumpulkan para menteri kerajaannya untuk meminta pendapat mengenai surat tersebut. Berikut adalah sikap Balqis terhadap surat yang dikirimkan oleh nabi Sulaiman, sebagaimana Firman Allah dalam surat an-Naml: 29-32:

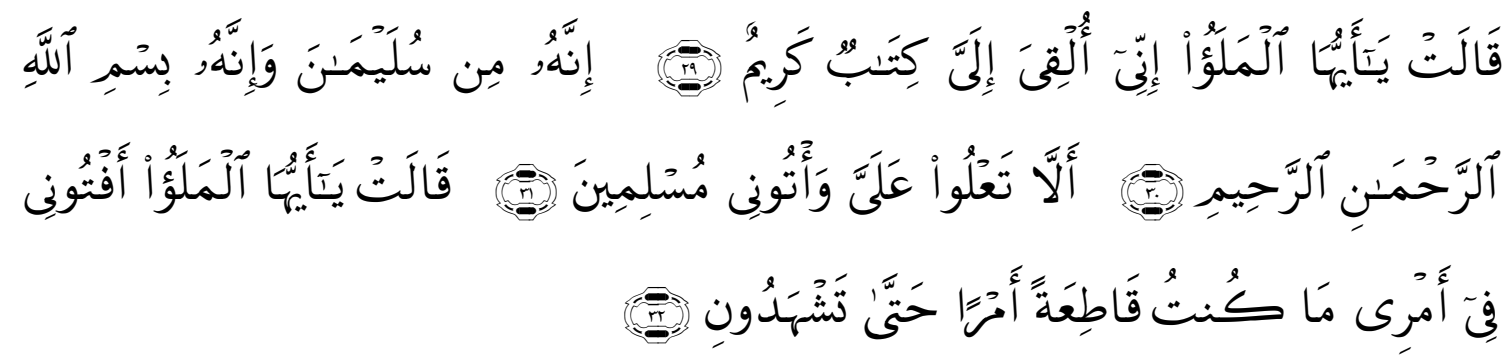

Artinya:"Dia (Balqis) berkata, "Wahai para pembesar! Sesungguhnya telah disampaikan kepadaku sebuah surat yang mulia."Sesungguhnya (surat) itu dari Sulaiman yang isinya "Dengan nama Allah yang Maha Pengasih, Maha Penyanyang, Janganlah engkau berlaku sombong terhadapku dan datanglah kepadaku sebagai orang-orang yang berserah diriku". Dia (Balqis) berkata,"Wahai para pembesar!, berilah aku pertimbangan dalam perkara(ku) ini. Aku tidak pernah memutuskan suatu perkara sebelum kamu hadir dalam majelis (ku)." (Q.S. an-Naml [27] : 29-32).

Ketika Balqis menerima surat tersebut ia langsung memberitahukan para menterinya dan membacakan surat tersebut dihadapan mereka ia pun meminta pendapat para pembesarnya dan bermusyawarah kira-kira apa yang akan dilakukan

\footnotetext{
${ }^{20}$ Sayyed Qutubi, Fỉ Dilal al-Qur'an, h. 296.
} 
terhadap surat tersebut. Dalam kitab tafsir Al-Misbah menjelaskan bahwa Balqis selalu meminta pendapat para menterinya terhadap suatu permasalahan baik permasalahan yang kecil, maupun permasalahan yang besar. ${ }^{21}$ Hal ini menunjukkan bahwa ia seorang pemimpin yang ideal yag tidak menyembunyikan sesuatu dari rakyatnya. Setiap ada permasalahan dan informasi ia langsung memberitahukan kepada rakyatnya baik berita yang menggembirakan maupun berita yang menyedihkan, meminta pendapat mengenai segala sesuatu dalam hal mengambil sebuah keputusan, tidak memaksa kehendak yaitu sama-sama memikirkan kesejahteraan rakyatnya dan memakmurkan rakyatnya, tidak memikirkan urusan pribadi dan tidak egois terhdap dirinya sendiri.

Ratu adalah seorang pemimpin dan mempunyai kedudukan yang tinggi dalam suatu pemerintahan. Seorang pemimpin memberikan perintah kepada bawahannya, dan bawahannya mengerjakan apa yang diperintahkan oleh atasanya. Dengan adanya musyawarah, maka akan tejalin hubungan yang harmonis demi meningkatkan suatu pemrintahan dan meningkatkan kesejahteraan rakyatnya. Pesan yang ingin disampaikan dalam ayat tersebut adalah apabila terdapat suatu permasalahan yang tidak dapat diselesaikan, maka cara yang ditempuh adalah dengan cara musyawarah. Ini menunjukkan akan perintah musyawarah apabila ada suatu perkara tertentu dan membutuhkan siasat atau stategi yang bagus dalam menyelesaikan suatu persoalanpersoalam atau permasalahan yang tidak dapat dapat dipecahkan dengan sendiri, maka persoalan tersebut dapat diselesaikan dengan jalan musyawarah yang menunjukkan sisi demokratisnya. Maka dari itu, metode yang digunakan Balqis dapat menyelesaikan suatu permasalahan yaitu dengan meminta pendapat para pembesar kerajaan, sehingga ia dapat mendengarkan pendapat-pendapat para pembesar sehingga dapat menambah wawasan aatu pandanagn baru terhadap permasalahan tersebut.

Sikap bijaksananya Balqis terhadap surat tersebut adalah ketika ia menerima suarat Nabi Sulaiamn ia menyebutnya dengan kitābun karim, ia tidak emosi serta tidak merobek-robek surat tersebut sebagaimana kebiasaan tradisi raja-raja sebelumnya. Tetapi ia menghargai surat tersebut dan memutuskan apa yang akan ia lakukan terhadap surat tersebut. Nampak sikap bijaksana yang terlihat dari Balqis serta memanggil para pembesar kerajaannya ketika terdapat suatu permasalahan.

\section{Pemimpin yang Diplomasi dan Cinta Damai}

Dalam ayat selanjutnya akan terjadi dialog antar Balqis dan menteri kerajaan mengenai reaksi dan sikap terhadap surat tersebut. Para pembesar kerajaan menyampaikan pendapat mereka bahwa kerajaannya memiliki kekuatan yang besar dan memiliki keberanian untuk berperang. Namun tetap menyerahkan keputusan akhir kepada Balqis, sebagaimana Firman Allah:

\footnotetext{
${ }^{21}$ Quraish Shihab, Tafsir Al-Misbah, h. 213.
} 


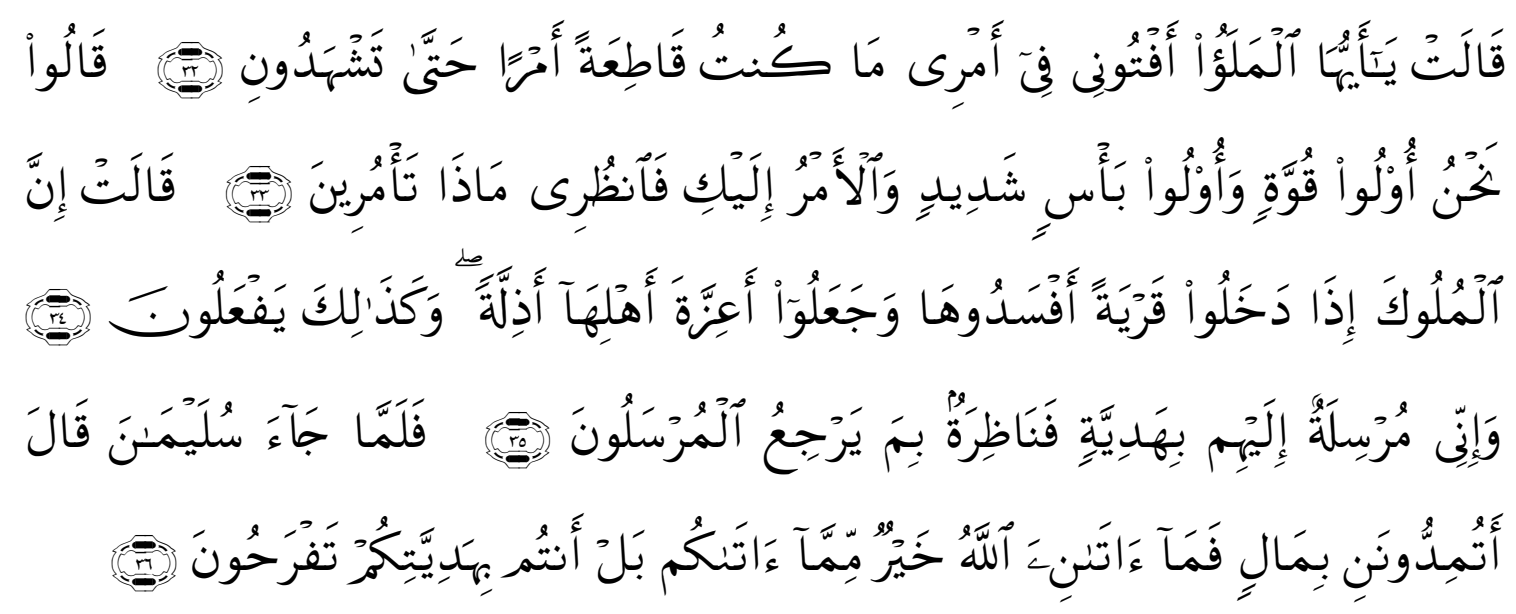

Artinya:"Dia (Balqis) berkata,"Wahai para pembesar!, berilah aku pertimbangan dalam perkara(ku) ini. Aku tidak pernah memutuskan suatu perkara sebelum kamu hadir dalam majelis ku. Mereka menjawab"kita memiliki kekuatan dan keberanian yang luar biasa (untuk berperang), tetapi keputusan berada di tanganmu, maka pertimbangkan apa yang engkau perintahkan. Dia (Balqis) Berkata,"Sesungguhnya raja-raja apabila menaklukkan suatu negeri mereka tentu membinasakan dan menjadikan penduduknya mulia jadi hina dan demikian yang mereka perbuay. Dan sungguh, aku akan mmengirimkan ut usan kepada mereka dengan (membawa) hadiah dan aku akan menunggu apa yang akan dibawa kembali oleh ut usan tersebut." (Q.S.an-Naml [27] : 32-36)

Dalam kitab tafsir Ibnu Katsir dijeaskan bahwa Balqis mengatakan kepada menterinya apabila mereka memasuki suatu negeri untuk menagadakan penyerangan dan mereka pasti menghancurkannya dan membinasakannya. Mereka mengincar para pembesar dan tentaranya untuk dihinakan serendah-rendahnya baik dengan cara membunuh atau menwannya. ${ }^{22} \mathrm{Hal}$ ini menunjukkan bahwa Balqis mengetahui serta menganalisis bahwa kebiasaan para raja sebelumnya dan merupakan perilaku seorang raja apabila telah memasuki suatu negeri maka mereka akan membuat kerusakan dan menghalalkan darah penduduknya, merusak kehormatan, menghancurkan kekuatan pemimpinnya. Mereka membuat para pemimpinnya menjadi hina, karena mereka merupakan unsur perlawanan. Hal tersebut menunjukkan bahwa Balqis belajar dari pengalaman dan kebiasaanraja-raja sebelumnya, dan ia tidak menginginkan hal yang sama juga terjadi pada kerajaannya. Dialog yang terjadi antara Balqis dan para menteri kerajaannya menunjukkan bahwa ia seorang yang diplomatis serta sangat menjaga ketentraman rakyatnya.

Dalam ayat tersebut menggunakan kata wa al-amru ilaiki (tetapi keputusan berada di tanganmu). Kalimat ini menarik untuk dilihat lebih lanjut. Kalimat tersebut menujukkan adanya etika atau suatu adab para pembesar kerajaan kepada Balqis selaku pemimpinnya, rasa hormat dan patuh terhadap perintahnya, menunjukkan akan para rakyatnya sangat setia, tunduk serta patuh kepada Balqis selaku pemimpin. Rasa hormat mereka kepada Balqis selaku pemimpin menunjukkan bahwa pemimpin meraka

\footnotetext{
${ }^{22}$ Ibnu Katsir, Tafsir al-Qur'ān al-Azìm, h. 403.
} 
adalah seorang pemimpin yang baik dan disegani. Maksudnya adalah jika pemimpinnya baik, maka rakyatnya pun kan segan, hormat serta menaati perintahnya dan tidak ada unsur paksaaan. Hal ini menunjukkan bahwa Balqis adalah pemimpin yang baik di mata rakyatnya, sehingga rakyatnya menjadi sejahtera dan makmur.

Balqis mencoba untuk melakukan diplomasi, perundingan sehingga mempunyai stategi dan trik lainnya yaitu dengan mengirimkan hadiah. Beliau tidak ingin berperang, karena mengetahui akan mengalami kerugian besar dan akan menyiksa penduduknya. Balqis akan mengutus seseorang untuk membawa hadiah yang pantas dan dia akan menunggu apa yang akan dijawabnya. Menurutnya hadiah dapat melunakkan hati, menyatakan cinta dan terkadang berhasil menghindari peperangan ini sekaligus merupakan ujian bagi Sulaiman.

Hal ini menujukkan bahwa nampak kepribadian seorang perempuan, dibalik kepribadian pgenghancuran seorang pemimpin yaitu sosok perempuan yang membenci perang dan penghancuran tapi lebih mengedepankan trik dan senjata stategis lainnya yaitu dengan senjata kelembutan dan tidak menggunakan senjata kekuasaan dan kekerasan. Qatadah berkata bahwa Balqis adalah wanita yang paling cerdik, baik pada masa keislaman maupun pada saat dia sebelum Islam. Ia mengetahui bahwa hadiah sangat berpengaruh terhdap manusia serta ingin menguji Sulaiman yaitu jika menerima pemberian tersebut berarti ia dalah seorang raja maka memeranginya dan apabila ia tidak menerimanya, berarti ia seorag rasul dan mengikuti ajaran yang dibawanya. ${ }^{23}$

Mengenai kata hadiyyah dalam ayat tersebut menarik untuk kita teliti lebih lanjut. Kata hadiyyah berasal dari akar kata yang terdiri dari huruf ha, dal dan ya. Asal katanya adalah hadā-yahdi-hadyan-hudan-hidyatan-hidāyatan yang artinya memberi petunjuk kepadanya. ${ }^{24}$ Frase hadā lahu atau ahdā ilaihi mempunyai arti memberikan hadiah atau menghadirkan kepadanya. Dalam ayat tersebut menggunakan kata hadiyyah yang merupakan mufrad (tunggal), jamaknya adalah hadāyā. ${ }^{25}$ Menurut Quraish Shihab maknanya berkisar atas dua hal. Pertama, tampil kedepan memberi petunjuk dan kedua, menyampaikan dengan lemah lembut. Dari makna kedua ini lahir kata hadiah yang merupakan penyampaian sesuatu dengan lemah lembut guna memberikan simpati kepada orang yang diberikan. ${ }^{26}$

Memang tidak dapat dipungkiri bahwa manusia tergiur dan terlena dengan hadiah padahal itu hanyalah kesenangan dunia dan hanya bersifat sementara. Dengan adanya hadiah sesorang akan lunak dan luluh akan mengerjakan apa yang diperintahkan dikarenakan ada sesuatu yang diharapkan dan sesorang tersebut pun akan diam dan tidak bisa berkata apa-apa. Hal ini menunjukkan bahwa sangat hebat dan ajaibnya suatu pemberian hadiah serta juga bisa menguji seseorang.

\footnotetext{
${ }^{23}$ Ibnu Katsir, Tafsir al-Qur'an al-Az̄im, h. 455.

${ }^{24}$ Mahmud Yunus, Kamus Arab-Indonesia, h. 18

${ }^{25}$ Mahmud Yunus, Kamus Arab-Indonesia, h. 234.

${ }^{26}$ Quraish Shihab, Tafsir Al-Misbah, h. 213.
} 


\section{Pemimpin yang Cerdas dan Teliti}

Sikap ketelitian dan kecerdasan balqis dapat kita lihat ketika Balqis dalam memutuskan sesuatu, ia menimbang dan menganalisis terlebih dahulu bagaimna kebiasan para raja terdahulu, sehinngga dapat mengambil pelajaran darinya, tidak secara terburuburu langsung memutuskan dan langsung ingin berperang, akan tetapi Balqis mempunyai trik sendiri bahwa ia ingin mengirimkan hadiah kepada Sulaiman, kemudian ingin melihat apa reaksi dari Sulaiman btersebut. Hal ini menunjukkan akan kecerdasan dan ketelitian Balqis dalam memutuskan suatu permasalahan. Ia tidak terburu-buru dalam mengambil keputusan akan berakibat fatal dan di kemudian hari. Oleh karena itu, ia harus dipertimbangkan dengan sebaik mungkin. Hal ini menunjukkan akan ketelitian dan kecerdasan serta kebijaksanaan Balqis dalam mengambil suatu keputusan.

Sikap ketelitian dan kecerdasan Balqis juga terlihat ketika Balqis dalam menjawab sebuah pertanyaan dari Sulaiman, sebagaimana firman Allah dalam Q.S.An-Naml: 42

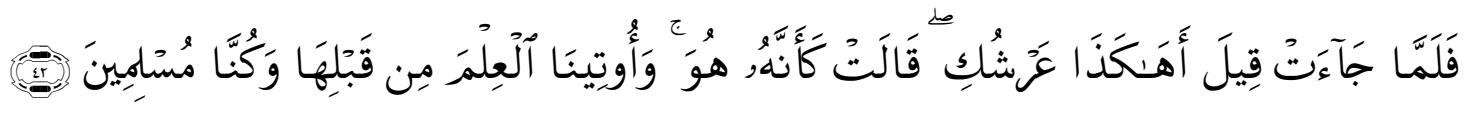

Artinya :"Maka ketika dia (Balqis) datang, ditanyakan (kepadanya), "Serupa inikah singgasanamu?" Dia (Balqis) menjawab, "Seakan-akan itulah dia, (Dan dia Balqis berkata,"Kami telah diberi pengetahuan sebelumnya dan kami adalah orang-orang yang berserah diri (kepada Allah). (Q.S.an-Naml [27] : 42).

Ketika Balqis sampai di kerajaan Sulaiman, ia bertanya: "Ahākazā 'arsyuki?' (serupa inikah singgsanamu?" dalam kalimat tersebut terdapat alif istifhām yang menunjukkan akan pertanyaan Sulaiman kepada Balqis. Balqis menjawab pertanyaan tersebut dengan kalimat “ka'annahü huwa” (seakan-akan itulah dia). Ka'anna adalah huruf tasybih (menyerupai atau seperti). Ia tidak menjawab dengan kalimat innahu huwa atau dengan kalimat yang lain yang menunjukkan bahwa itu bukan singgsananya. Ia menjawab dengan jawaban ka'annahu huwa, jawaban tersebut sesuai dengan pertanyaan dari Sulaiman dan juga sesuai kondisi yang dialaminya pada saat itu. ${ }^{27}$

Ketika singgasana tersebut diperlihatkan kepada Balqis ia tidak langsung mengatakan itu sebagai singgsananya, karena kejauhan jaraknya, dan ia pun tidak mengatakan itu bukan singgasananya, karen ia melihat sifat-sifat dan tanda-tanda yang sama, sekalipun telah diubah dan ditambah. Ia menjawab ka'annahu huwa yaitu keserupaan dan hampir samanya dengan singgasana yang ditinggalkannya di kerajaan Saba'. Jawaban tersebut menunjukkan akan kecerdasan dan kepandaain yang luar biasa. Ia tidak langsung terkecoh dengan ciri-ciri singgasananya yang sama dengan singgasananya. Singgasananya pun telah dijaga oleh prajurit dengan aman dan kuat sehingga tidak mungkin singgasananya berada di hadapannya. Hal ini mengisyarakatkan bahwa Balqis sangat teliti, maksudnya adalah ia tidak sembarangan menjawab tetapi memikirkan dan memutuskan dengan sebaik-baiknaya apa yang akan dijawabnya.

\footnotetext{
${ }^{27}$ Sahiron Sayamsuddin, Hermeneutika dan Pengembangan Ulumul Qur'an (WonoSari: Pesantren Nawesa Pres, 2009), h. 96.
} 
Setelah Balqis menyaksikan dan melihat langsung akan kemegahan Sulaiman, kekuasaan serta kebesaran Allah, ia meyatakan masuk islam bersama Sulaiman, sebagaimana Firman Allah:

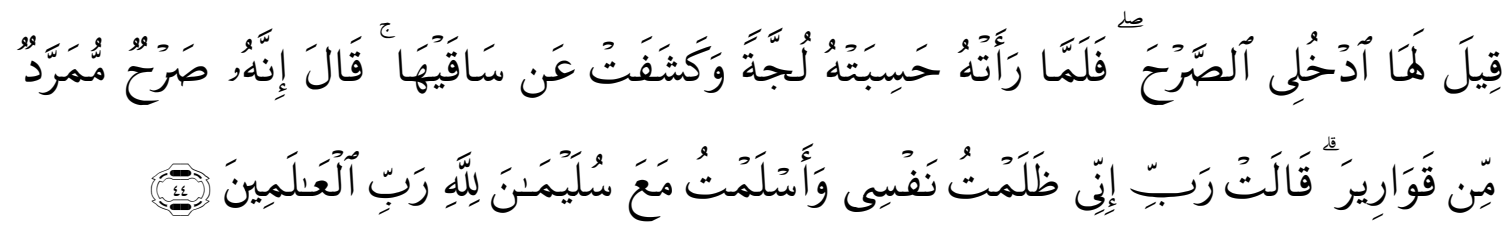

Artinya: Dikatakan kepadanya (Balqis), "Masuklah ke dalam istana, maka ketika ia Balqis melihat (lantai istana) itu, dikiranya kolam air yang besar dan disingkapkan (penutup) kedua betisnya. Dia (Sulaiman) berkata, Sesungguhnya ini hanyalah lantai istana yang dilapisi kaca."Dia (Balqis) berkata "Ya Tuhanku, sungguh, aku telah berbuat zalim terhadap diriku. Aku berserah diri bersama Sulaiman kepada Allah, Tuhan seluruh alam." (Q.S.AnNaml [27] : 44)

Ayat ini menunjukkan bahwa Balqis pada mulanya menjadi pemimpin Saba' dalam keadaan tidak berimana kepada Allah. Ketika Balqis melihat kebesaraan Allah dan kekuasaan Allah yang diberikan kepada Sulaiman, ia menyatakan Islam yaitu berserah diri bersama Sulaiman kepada Allah. Hal ini menunjukkan bahwa sebelum beriman saja Balqis mampu memimpin dan memakmurkan negerinya, apalagi, setelah beriman bersama Sulaiman.

Berdasarkan uraian tersebut dan penjelasan terdahulu menunjukkan bahwa Alquran telah menggambarkan bagaimana karakteristik kepemimpinan Balqis dalam memimpin negeri Saba' yang mendapat julukan baldatun tayyibatun wa rabbun ghafür.

\section{Penutup}

Secara eksplisit, Alquran tidak menjelaskan secara tegas tentang kepemimpinan perempuan. Oleh karena itu, terjadinya kontroversi serta perbedaan pendapat mengenai isu tentang kepemimpinan perempuan, dikarenakan pemahaman yang berbeda dalam memahami ayat tersebut. Akan tetapi, Alquran telah mendokumentasikan keberadaan kepemimpinan perempuan yaitu Balqis yang diabadikan dalam surat al-Naml: 23-44. Hal ini menunjukkan bahwa pernah ada sosok perempuan yang menjadi pemimpin.

Alquran surat al-Naml: 23-44 bukan hanya mengambarkan keberadaan kepemimpinan perempuan saja, aka tetapi juga memaparkan karakteristik Balqis dalam memimpin negeri Saba', seperti demokratis, bijaksana, cerdas, teliti, cinta damai dan diplomasi. Ini menunjukkan bahwa dalam diri Balqis mempunyai karakteristik dan sifat-sifat kepemimpinan dalam memimpin suatu pemerintahan. Karakteristik kepemimpinan yang dimiliki oleh Balqis juga bagus. Hal ini menunjukkan bahwa Islam memberikan peluang atau tidak membatasi ruang gerak perempuan dalam berkratifitas dan berprestasi sesuai dengan skill dan keahliannya. 
Tulisan ini diharapkan dapat menjadi referensi serta wawasan tambahan bahwa pernah ada sosok perempuan yang memimpin yang diceritakan secara khusus dalam Alquran, sehingga dapat menjadi pencerahan serta dapat mengubah cara pikir masyarakat agar tidak mendiskriminasikan sosok pemimpin perempuan. Apabila terdapat sosok perempuan yang mampu dan memiliki karakteristik kepemimpinaan yang baik, maka tidak ada salahnya ia menjadi seorang pemimpin. Bagi kaum perempuan lainnya walaupun aktif dan eksis dalam sektor publik, tidak melupakan kodratnya sebagai perempuan yaitu ibu atau istri, dan tidak melenceng norma-norma agama. Apabila telah diembankan suatu amanah harus disyukuri dan tetap terus berkarya untuk menghasilkan segala sesuatu yang bermanfaat yang dapat dirasakan oleh masyarakat pada umumnya dan untuk kemajuan suatu pemerintahan. 


\section{DAFTAR PUSTAKA}

A. Hajsmi. 59 Tahun Aceh Merdeka di Bawah Kepemimpinan Ratu. Jakarta: Bulan Bintang, 1977.

Ahmad Ath-Thahari, Hamid. Kisah-Kisah dalam Alquran. Bandung: Irsyad Baitus Salam, 2012.

Al-Ashfahani, Muhammad Husain. Mufradat fi Gharib al-Quran. Beirut: Darul Makrifah, $502 \mathrm{H}$.

Amin Suma, Muhammad. Ulumul Qur'an. Jakarta: RajaGrafindo Persada, 2013.

Awar, Saifuddin. Metodologi Penelitian. Yogyakarta: Pustaka Pelajar, 2004.

Haitsam al-Khayyath, Muhammad Problematika Muslimah Di Era Modern. Jakarta: Gelora Aksara Pratama, 2007.

Katsir, Ibnu. Tafsir al-Quran al-Azìm.Beirut: Dār al-Ma'rifah.

Imron,Ali. Semiotika Alquran: Metode dan Aplikasi Terhadap Kisah Yusuf. Teras: Jakarta, 2011.

Khatimah,Khusnul. Semiotika: Sebuah Pendekatan dalam Studi Agama Komunika: Jurnal Dakwah dan Komunikasi, Vol. 2 No. 2. 2008

M. Karyadi. Kepemimpinan. Bandung: Karya Nusantara, 1989.

Nawawi, Hadari. Kepemimpinan Menurut Islam Yogyakarta: Gajah Mada Universitas Pres, 1998.

Qutub, Sayyed. Fi Dhilal al-Qur'an Terj.M. Misbah \& Aunur Rafiq Shalih Tamhid Jakarta: Rabbani Pres, 2009.

Shihab, Quraish. Tafsir Al-Misbah: Pesan, Kesan dan Keserasian Alquran. Jakarta: Lentera Hati, 2002.

Syamsuddin, Sahiron. Hermeneutika dan Pengembangan Ulumul Quran WonoSari: Pesantren Nawesa Pres, 2009.

Syafieh, "Perkembangan Filsafat Falsafi Dalam Ranah Pemikiran Islam:, Jurnal AtTibyan, Vol. II Nomor 2 (Desember 2017)

Tim Penyunting. Kamus Besar Bahasa Indonesia Jakarta: Departemen Pendidikan dan Kebudayaan, 1998.

Yunus, Mahmud. Kamus Arab-Indonesia. Jakarta: Hidakarya Agung, 1989.

Al-Zamakhsyarī. Tafsīr al-Kasysyāf, Beirūt: Daral-Ma'rifah. 